\title{
The influence of englacial drainage on sediment-transport pathways and till texture of temperate valley glaciers
}

\author{
MARTIN KIRKBRIDE \\ Department of Geography, University of Dundee, Dundee DD1 4HN, Scotland \\ Nick SPEDding* \\ Department of Geography, University of Edinburgh, Drummond Street, Edinburgh EH8 9XP, Scotland
}

\begin{abstract}
Field studies at Mueller and Tasman Glaciers in New Zealand and in Iceland have revealed extensive ice-marginal moraine sequences fed by a series of debris bands containing characteristic rounded debris. We interpret these debris bands as meltwater deposits from relict conduits. The process of sediment accumulation described requires that debris undergoing basal or high-level ice transport is entrained by running water, becoming comminuted and rounded before being returned to highlevel ice transport and eventual deposition in marginal moraines. This sequence of events suggests a link between glacier hydrology and ice-marginal sedimentation, possible mechanisms for which are explored. Pronounced moraines with rounded debris can be expected if (a) a large quantity of debris is carried within the englacial drainage network; (b) there is a tendency for this debris to be abandoned within the ice; and (c) ice-flow trajectories and ablation ensure that this debris congregates at the ice surface. Streams which flow at high level within the ice can intercept and entrain englacial debris derived from rock fall. However, debris sources at Gigjökull and Steinholtsjökull in Iceland are restricted to the glacier bed, suggesting that, in certain cases, the presence of a basal overdeepening acts as a key factor controlling the accumulation of these moraines. Water pressure rises as channels encounter an overdeepening, forcing debris-laden streams to leave the bed and take an englacial route. That debris may pass from ice to water and back into ice before deposition has gone largely unrecognised in accounts of glacial process systems, yet it provides an explanation of how temperate alpine glaciers can include water-worked debris in their marginal depositional facies.
\end{abstract}

\section{INTRODUCTION}

Understanding of the internal hydrology of glaciers has expanded substantially in recent years. Increasingly, links are being demonstrated between basal water flow, changing dynamics of ice flow and subglacial erosion processes. However, the implications which different styles of drainage behaviour might have for the development of glacial landforms remain underexplored, although it is logical to expect that such linkages will be important. Glacier hydrology potentially exerts an influence on depositional geomorphology, which suggests the need to reappraise current interpretation of ice-marginal sediment facies. This paper takes a first step in this direction by examining relationships between ice flow, englacialwater routeways, and sediment transport.

Sediment-transport pathway theory tends to be rigid. Most models imply that once debris is entrained, whether

* Present address: Department of Geography, University of Aberdeen, Elphinstone Road, Aberdeen AB9 2UF, Scotland. supra- or subglacially, the transport pathway followed is predetermined by the flow structure within the ice (Boulton, 1978). Exchanges between transport paths exist at important locations, particularly where debris is raised from the basal transport zone (e.g. at thermal or rheological boundaries) or lowered into it by basal melting (Kirkbride, 1995). These exchanges are generally implied to be one-way and irreversible. More recently, the importance of englacial waterways as sedimenttransfer routes in temperate glaciers has become more widely appreciated (e.g. Hooke and others, 1985; Evenson and Clinch, 1987), but sediment so routed is usually assumed to be evacuated beyond the ice margins by the meltwater.

Within this conceptual framework, it is difficult to account for the abundant rounded clasts and sorted sand and silt often found within the marginal moraines of temperate glaciers. Transport-pathway theory provides few opportunities for rounded material to become widely distributed throughout the high-level transport zone, as the clast-shape composition of many of these marginal moraines implies. Rounded clasts are usually explained as originating in proglacial fluvial sediment which has been 
overridden and recycled by advancing glacier ice (e.g. Slatt, 1971), or are interpreted as sediments carried within the basal traction zone (e.g. Matthews, 1987).

In this paper we describe field evidence which suggests more complex transport histories at glaciers in New Zealand and Iceland. This indicates that debris can be exchanged between ice and water transport at different levels within a glacier. We consider the mechanisms which might be responsible for such interchange.

\section{METHODS}

Field-work was undertaken at Mueller and Tasman Glaciers in the central Southern Alps of New Zealand $\left(43^{\circ} 42^{\prime} \mathrm{S}, 170^{\circ} 05^{\prime} \mathrm{E}\right.$ and $43^{\circ} 30^{\prime} \mathrm{S}, 170^{\circ} 15^{\prime} \mathrm{E}$, respectively), and at Gigjökull and Steinholtsjökull, outlet glaciers of the Eyjafjallajökull ice cap in southern Iceland $\left(63^{\circ} 40^{\prime} \mathrm{N}\right.$, $19^{\circ} 40^{\prime} \mathrm{W}$ ). All are located in temperate maritime regions in which both precipitation and debris production are high.

Aerial photographs plus extensive field-work were used to map the disposition of supraglacial debris as an indicator of transport pathways. To begin with, different debris types were identified on the basis of their field relations (i.e. relative to ice structure and flow pattern), followed by clast-shape measurements of samples taken from each group. These measurements identified the basic characteristics common to each debris type, enabling us to discriminate between categories. Two measures of clast shape were used. Clast roundness was assessed using the six-point scale of Powers (1953), and a mean numerical value for each sample obtained by assigning 1 to the very angular category through to 6 for the well-rounded category. Thus, increasing numerical values reflect a higher proportion of rounded material in the sample (Ballantyne, 1982). The $\mathrm{C}_{40}$ flatness index (\% of clasts in sample with $c$ axis/ $a$ axis $\leq 0.4$ (Ballantyne, 1982)) was chosen for use with the New Zealand data as the best measure of clast form, although it was of little use with the Icelandic data because different debris types showed little variance in form. Table 1 summarises the results of the sediment analysis.

\section{DEBRIS TRANSPORT AT MUELLER GLACIER}

The tongue of Mueller Glacier is completely mantled by supraglacial debris, derived by rock fall and avalanche from the $2000 \mathrm{~m}$ high east face of Mount Sefton. Most of the debris mantle is angular material mean roundness 1.88 with a wide range of clast form (mean flatness index $43 \%$ ). However, a sinuous swath of rounded gravel can be traced across the surface from the right margin $\mathrm{A}$ in Fig. la) to the centre of the glacier at its terminus. These gravels clearly reflect water transport and deposition within the ice. Field work in 1987 revealed them to be associated with an englacial stream which ablation had exposed at the glacier surface.

\section{Water routeways}

Also in 1987, a river emerged from the southern margin of the glacier $1.5 \mathrm{~km}$ above the terminus, and flowed subaerially for $400 \mathrm{~m}$ before re-entering the ice at a twin portal (A in Fig. 1a). The glacier surface stood at least $12 \mathrm{~m}$ above the portal, and was covered with tarnished angular debris containing distinct bands of freshly exposed, untarnished rounded clasts. These were taken to be the product of recent water transport, although site topography made supraglacial stream flow here impossible. $400 \mathrm{~m}$ down-glacier, collapse of a conduit roof had revealed what was assumed to be the same river flowing through a $100 \mathrm{~m}$ long doline, the flat floor of which was covered by water-worked sediment (B in Fig. la; Fig. 2). The river discharge was estimated to be less than that of the river entering the glacier at A. Several lenses of rounded debris were exposed in the ice walls of the doline, although the surrounding supraglacial mantle contained very little rounded debris. $150 \mathrm{~m}$ down-glacier, recent roof collapse had opened a small cave-like doline $\mathrm{C}$ in Fig. 1a), within which no river was visible, although running water could be heard beneath the doline floor. All exposures of ice observed were of englacial facies, and no basal ice was seen.

These observations demonstrate the presence of conduit flow well above the glacier bed. The fall in

Table 1. Summary of clast-shape data

\begin{tabular}{|c|c|c|c|c|c|}
\hline Sludy sile & Calegory & $\begin{array}{l}\text { Number of } \\
\text { clasts in sample }\end{array}$ & $\begin{array}{l}\text { Mean } \\
\text { roundness }\end{array}$ & $\begin{array}{c}\text { Mean } C_{10} \\
\text { flatness index } \\
\qquad \%\end{array}$ & Sample Nos. \\
\hline Mueller Glacier & $\begin{array}{l}\text { Rock fall } \\
\text { Water-worked debris }\end{array}$ & $\begin{array}{l}400 \\
200\end{array}$ & $\begin{array}{l}1.88 \\
3.42\end{array}$ & $\begin{array}{l}43 \\
30\end{array}$ & $\begin{array}{l}\text { M1-M8 } \\
\text { M9-M12 }\end{array}$ \\
\hline Tasman Glacier & $\begin{array}{l}\text { Rockfall } \\
\text { Debris from basal ice } \\
\text { Water-worked debris }\end{array}$ & $\begin{array}{l}400 \\
500 \\
400\end{array}$ & $\begin{array}{l}1.94 \\
2.43 \\
2.88\end{array}$ & $\begin{array}{l}48 \\
32 \\
23\end{array}$ & $\begin{array}{c}\text { Т1-Т8 } \\
\text { T9-T18 } \\
\text { T19-T26 }\end{array}$ \\
\hline Gigjökull east & $\begin{array}{l}\text { Debris from basal ice } \\
\text { Water-worked debris }\end{array}$ & $\begin{array}{l}396 \\
126\end{array}$ & $\begin{array}{l}2.60 \\
3.47\end{array}$ & - & $\begin{array}{l}\mathrm{G} 1-\mathrm{G} 6 \\
\mathrm{G} 7-\mathrm{G} 8\end{array}$ \\
\hline Gigjökull west & Water-worked debris & 487 & 3.83 & - & G9-G16 \\
\hline Steinholtsjökull & Water-worked debris & 365 & 3.38 & & $\mathrm{~S} 1-\mathrm{S} 5$ \\
\hline
\end{tabular}



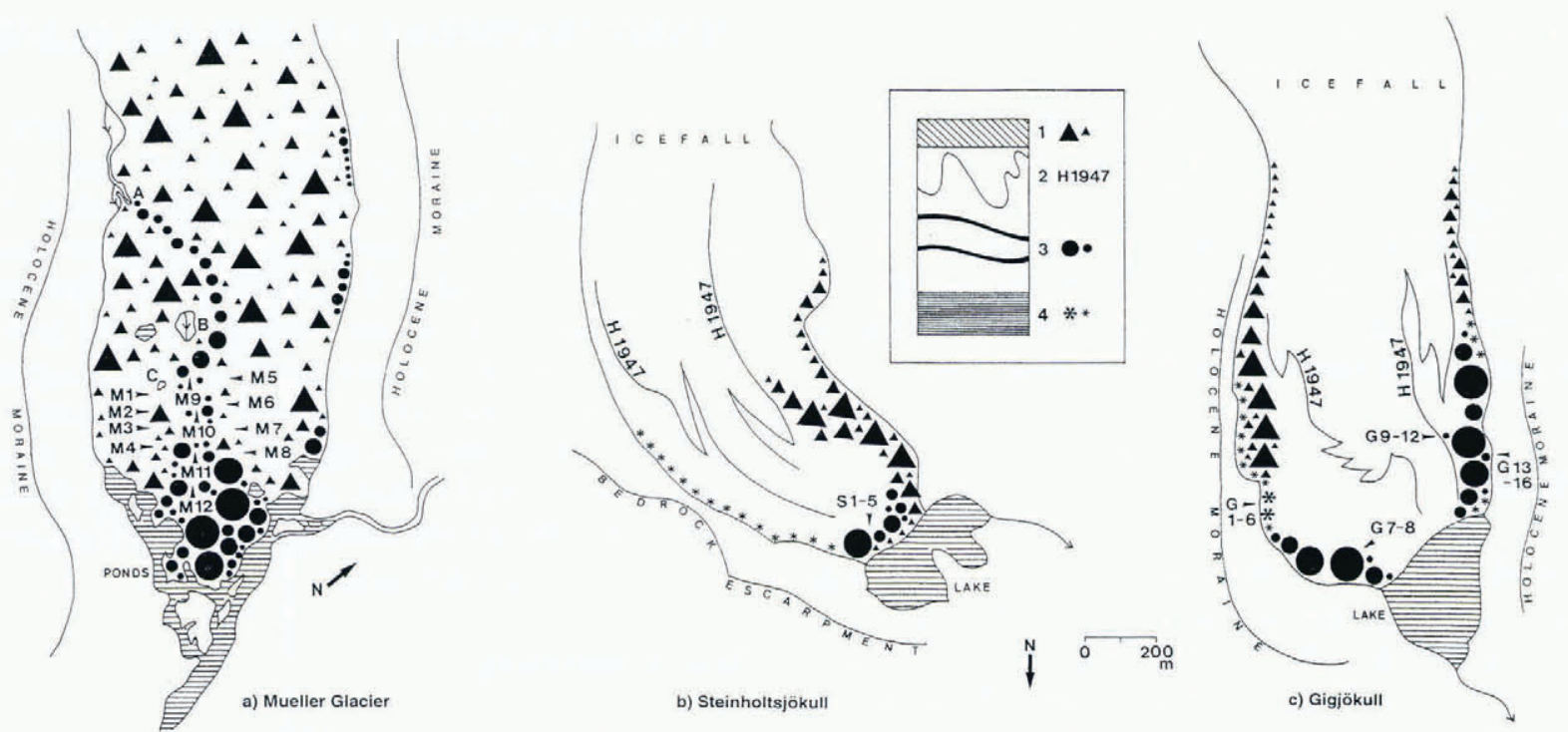

Fig. 1. Termini of Mueller Glacier (a), Steinholtsjökull (b) and Gigjökull (c), drawn to the same scale, and showing the distribution of debris types. Sample numbers (arrows) refer to samples in Table 1. Letters on Mueller Glacier refer to locations mentioned in the text. Inset: stratigraphic relationships at Gigjökull and Steinholtsjökull. Map symbols: 1, supraglacial rock-fall debris; 2, Hekla 1947 ash fall; 3, englacial-debris bands/water-worked supraglacial debris; 4, basal ice and debris.

discharge between the river entering the glacier and the river exposed in the large doline indicates division of the conduit within the glacier. The ice thickness is not known, but foliation in the ice, dipping steeply up-glacier, indicates that the exposed locations are probably tens of metres above the bed. Neighbouring glaciers with similar morphology all occupy basins behind their proximal moraines and outwash; similarly, we expect Mueller Glacier to have an "overdeepening" below its terminus: reasoning supported by the presence of a lake impounded between the ice front and the adverse slope of the proglacial depression.

\section{Surface exposures}

The sinuous train of rounded debris occupies a pronounced depression in the glacier surface, which broadens down-glacier into a fan-like form extending into the proglacial ponds at the glacier terminus. The origin of the depression is most likely to have been by conduit collapse and ice-wall back-wasting as observed at the nearby dolines. The distance between the dolines studied in 1987 and this depression, which formed at an earlier date, suggests that the englacial conduit has switched course to the southwest. The debris itself is distinct from the surrounding rock-fall debris, its unweathered light grey tone, indicating recent exposure at the glacier surface, contrasting with the tarnished material elsewhere. Clastshape properties (Table 1) give a mean roundness value of 3.42 and a mean flatness index of $30 \%$. Small-scale structures diagnostic of water transport include imbrication, boulder clusters and nascent bar/chute forms, usually deformed by differential ablation of the ice beneath following deposition. Significantly, no surface water flow was observed, nor have we reason to believe that supraglacial flow capable of reworking large quantities of debris was common here prior to recent conduit exposure. By April 1995, the dolines observed in 1987 had ablated and merged with the earlier-formed depression, and the area of water-rounded debris had widened.

\section{Ice-cave exposures}

A debris band was exposed in the ice wall of the small doline ( $\mathrm{C}$ in Fig. 1a). The $2.5 \mathrm{~m}$ thick band dipped upglacier at $25^{\circ}$, cross-cutting the much steeper angle of foliation in coarse bubble-rich ice. It contained mostly sub-angular to rounded clasts in a poorly sorted sand/ granule matrix cemented by ice. Locally within the matrix, stratification was well developed; elsewhere it was massive. Linear clast-supported boulder clusters, parallel to the overall trend of the debris band, were interlayered with matrix-supported diamict. The upper and lower debris-ice contacts were sharp, and the surrounding ice was clean. The debris band is interpreted as an abandoned conduit fill subsequently back-tilted by compressive flow of the ice.

\section{Interpretation}

Several factors are responsible for the observed disposition of drainage and debris types. Exposure of the englacial conduit has mainly been due to glacier thinning since the turn of the 19th century. A detailed unpublished map from 1906 by T. N. Brodrick shows no record of water-worked sediment at the glacier surface, but records a large river emerging from terminal ice cliffs. Glacier thinning of at least $120 \mathrm{~m}$ has brought the water-worked debris to the surface. However, the emergence velocity of the ice must also be taken into account. Pronounced upward motion within strongly compressive flow will elevate any debris within the ice. The same will not be true of active conduits, which tend to find successively lower levels within the ice, so that only the abandoned conduit fills reach the surface, and not the flowing water. Evidence of channel division in 1987 suggested that water was in the process of abandoning 


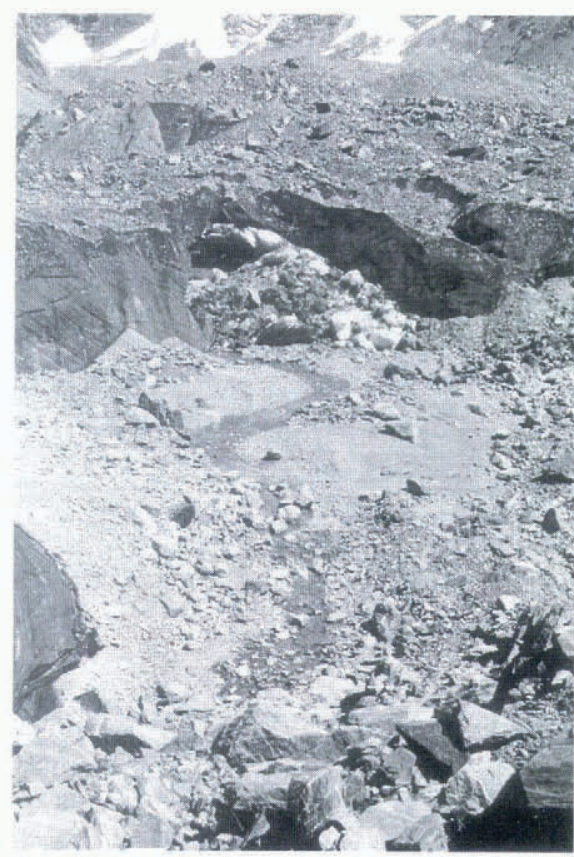

a

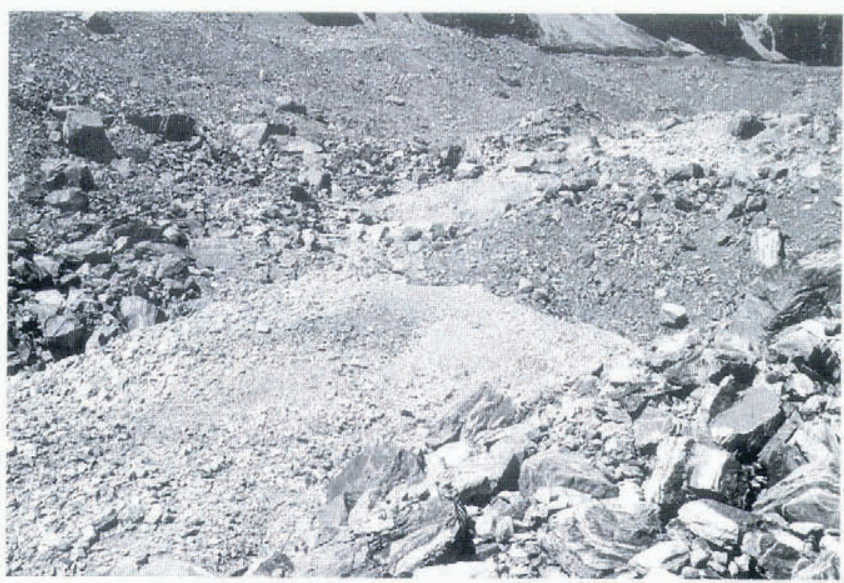

b

Fig. 2. (a) Mueller Glacier: view downstream of the large collapsed doline (al B, Fig. Ia) in 1987, showing unweathered water-rounded gravel on the doline floor, back-wasting walls of bare ice (dark) and larnished rockfall debris mantling the surrounding ice surface. The river disappears into an englacial conduit and does not re-emerge above the terminus. (b) Mueller Glacier: view downstream of the sinuous train of water-worked debris at its narrowest point on the glacier surface, close to A in Figure la.

the routeway through the large doline (B), having already abandoned the conduit fill exposed in the small doline $(\mathrm{C}$ ) to occupy a route at a lower level.

\section{DEBRIS TRANSPORT AT TASMAN GLACIER, NEW ZEALAND}

The lower $10 \mathrm{~km}$ of Tasman Glacier is also completely mantled by supraglacial debris. Though predominantly rock-fall-derived, material from the basal traction zone is elevated along an ice-stream confluence (Kirkbride, 1995, fig. $8.7 \mathrm{~b})$. Towards the terminus an increasing proportion of water-rounded debris occurs as down-glacier-aligned stripes and patches among the supraglacial debris. A rough estimate would be that as much as $5 \%$ of the debris mantle consists of rounded material. This is unweathered compared to the supraglacial rock-fall material, as with Mueller Glacier, again indicating recent exposure at the ice surface. Nowhere in the lower $8 \mathrm{~km}$ of the glacier is there the possibility of supraglacial stream flow reworking rock-fall debris, but some areas of rounded debris are associated with funnel-shaped thermokarst sinkholes, caused by roof collapse above englacial conduits (Kirkbride, 1993). The contrast in clast shape between the water-worked and rock-fall debris is again evident (Table 1). Additionally, outcrops of basal traction-zone debris allowed samples to be taken, something which was impossible at Mueller Glacier. Table 1 shows the distinction between water-worked and basal clasts by roundness and, more subtly, flatness index.

The down-glacier increase in the quantity of rounded supraglacial debris again indicates effective waterreworking of sediment in englacial positions, with debris subsequently returned to transport in ice to be elevated by compressive flow to the glacier surface. The presence of a large overdeepening beneath the terminus of Tasman Glacier has been demonstrated by a variety of geophysical surveys Broadbent, 1973; Hochstein and others, 1995). Conduits exposed by roof collapse in the 1970s were located at a high level in marginal positions within actively flowing ice (Kirkbride, 1993).

\section{DEBRIS TRANSPORT AT GIGJÖKULL AND STEINHOLTSJÖKULL, ICELAND}

Both glaciers exhibit similar geomorphic and sedimentary relationships, with large areas of moraine actively forming in the terminal zones. Figure $1 \mathrm{~b}$ and $\mathrm{c}$ illustrate the distribution of debris types. Four distinct categories are identified:

(1) Rock fall directly onto the ice surface. This is important below the equilibrium line (EL) only; within the accumulation area $(>1100 \mathrm{~m})$ the area of exposed bedrock is negligible. Rock-fall debris is everywhere distinct because of its high angularity, its colour (commonly brown rather than grey) and its position on the ice surface at the highest transport level. Although its volume is significant, it is not considered further in this paper.

(2) Volcanic ash from the Hekla 1947 eruption. This occurs as a thin $(<2.0 \mathrm{~cm})$, tightly folded but coherent layer within the englacial ice. Only its up-glacier outcrop is shown in Figure $1 \mathrm{~b}$ and $\mathrm{c}$, below which the ice is covered with a patchy spread of tephra. However, the contribution of the tephra to the total volume of sediment is negligible.

(3) Debris derived from a multiple series of englacial-debris bands. These account for the bulk of sediment currently contributing to moraine formation, and are discussed in detail below.

(4) Debris derived directly from extensive sequences of crudely stratified basal ice. If present, air bubbles are flattened, and aligned in distinct layers which alternate with 
layers of fine debris, with the occasional inclusion of larger clasts. These tend to be angular to sub-angular, with a mean roundness of $2.60(n=396$, samples $\mathrm{G} 1$ G6).

\section{Englacial-debris bands}

A stacked series of debris bands and channel fills exists at both glaciers between the Hekla 1947 tephra layer and the basal ice. These debris bands typically dip up-glacier, are $5-20 \mathrm{~cm}$ thick, laterally continuous for several tens of metres, and feed a series of overlapping moraine ridges (Fig. 3). Whereas crevasse exposures show the tephra layer to be highly convoluted in section, the debris bands appear to be gently warped. Assuming that the tephra is folded during its passage through the extensive icefall of each glacier, an origin below the icefall for the debris bands is indicated.

The character of the debris, and its relationship with the surrounding ice, is distinctly different from that of the basal debris. The debris bands are made up of sediment which has ice within the interstices, rather than ice which contains debris (mean debris content by mass of five debris band samples $73.7 \%$, s.d. $\pm 3.5 \%$; of 42 basal ice samples, $13.1 \%$, s.d. $\pm 11.9 \%$ ). The bands are enclosed by clear, coarsely crystalline ice in which bubbles are common and evenly distributed, properties which suggest that the ice has never been in contact with the glacier bed. Electrical conductivity (EC) measurements further differentiate between the two types of ice. Mean EC of melted samples of basal ice was $29.0 \mu \mathrm{s} \mathrm{cm}^{-1}$ $\left(n=44\right.$, s.d. $\pm 16.4 \mu \mathrm{s} \mathrm{cm}^{-1}$, measured at ambient temperatures of $10-14^{\circ} \mathrm{C}$ ), whereas four samples of melted englacial ice taken immediately above and below the debris bands registered 1.4, 1.6, 1.7 and $2.1 \mu \mathrm{sm}^{1}$. Although it is possible that this clear ice has been in contact with the bed without major modification, the contrast with the thick $(>10 \mathrm{~m})$ and welldeveloped sequences of what we identify positively as basal ice suggests otherwise. If the "englacial" ice is really "basal", a high degree of differential basal ice formation is required. Furthermore, sediment from these "englacial" debris bands is found on the surface of Gigjökull $>10 \mathrm{~m}$ above the sharp contact between "englacial" and debris-rich ("basal") ice. The simplest explanation is that the contrast between "englacial" and "basal" ice is genuine.

Clast-shape properties also are distinctly different. Debris-band clasts appear as significantly more rounded, with scores between 3.30 and 3.92 (Table 1). The samples fall into two groups, the second being the more rounded: S1-S5 plus G7 and G8 (Steinholtsjökull plus Gigjökull east) and G9-G16 (Gigjökull west). Using Student's ttests, not only are both distinguishable from the basal debris $(\mathrm{G} 1-\mathrm{G} 6)$, but the two groups themselves are also different at the $99.5 \%$ probability level.

\section{Interpretation}

As with Tasman and Mueller Glaciers, the sub-rounded/ rounded nature of the debris indicates it has been subject to the action of running water, and the field relationships of the debris bands suggest that at least the final part of

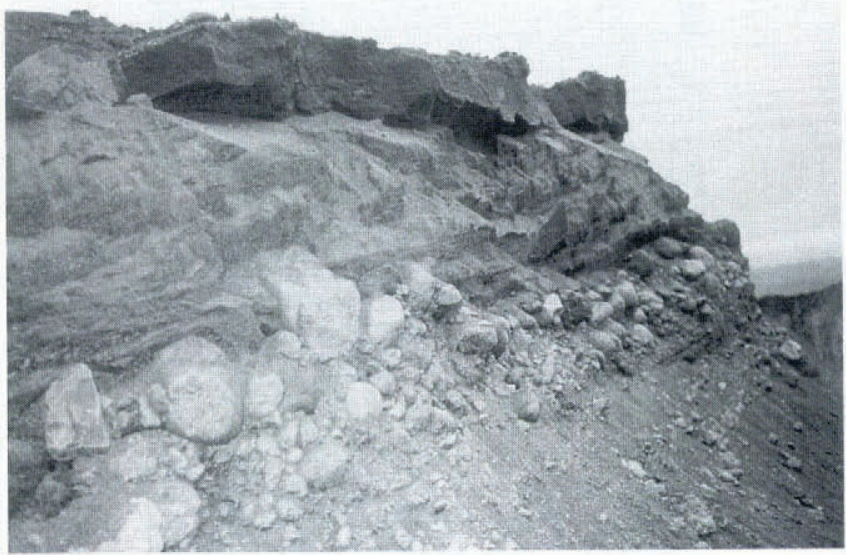

a

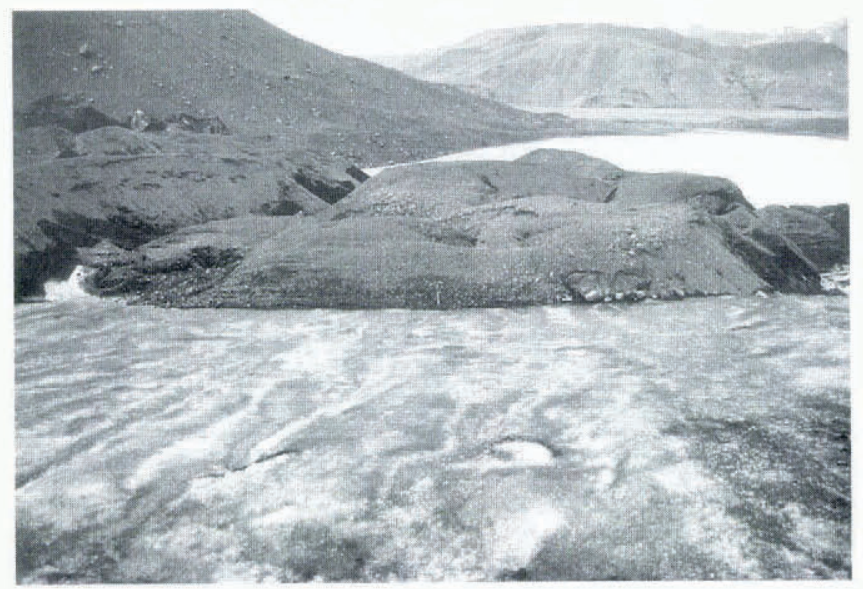

b

Fig. 3. (a) Gigjökull: close-up view of large pocket of water-worked sediment. Note crude sorting and stratification. This debris sits on the surface several metres above the englacial/basal ice conlact, and is preserved largely intact after the mell of interstitial ice. (b) Gigjökull: moraine complex fed by emerging bands of water-worked debris (ice-axe for scale). Note sharp contact between debris outcrop and relatively clean englacial ice.

this happens within an englacial conduit(s). The relationship of the debris bands to the tephra suggests that the process by which this debris is re-entrained by ice occurs in the region below the icefalls. In turn this implies that at least part of the internal drainage of the terminal lobes of Gigjökull and Steinholtsjökull is through englacial rather than subglacial routeways. The presence of a proglacial lake, as at Mueller Glacier, leads us to suspect an overdeepening exists below this zone at each glacier. That the debris from the western sample sites at Gigjökull is significantly more rounded suggests that conduit drainage is better developed here than beneath the eastern side of Gigjökull and beneath Steinholtsjökull in general.

\section{DISGUSSION}

\section{Origin of the debris}

Much of the moraine presently accumulating at the edge of the study glaciers appears to have reached the ice 
margin by a mechanism which is not easily explained by a straightforward transport-pathway model. A large proportion of the debris reflects transport by running water and clast modification by the action of turbulent flow, yet it is deposited directly out of englacial ice.

Existing theory tends to distinguish between distinct and separate transport pathways associated either with ice itself or with water within or beneath ice. Each involves distinct processes of clast modification, and ultimately produces a distinct landform, either glacial (moraines) or fluvioglacial (eskers, etc.). Sediment may be entrained by ice initially, but once it reaches the glacial drainage network, it is assumed "lost" to water transport, whereupon it is either carried away beyond the ice margin, or accumulates within a conduit to form an esker. In this case, however, sediment characteristic of water transport is deposited directly out of ice. We interpret the debris bands from which this sediment is derived to represent relict conduits. Thus, debris initially transported by ice (whatever its source and level of transport) is subsequently entrained by water, and carried some distance, sufficient to permit modification to clast shape, before passing back to high-level transport (i.e. above the basal transport zone (Boulton, 1978)) within the ice, and eventual deposition at the ice margin. Transport pathways within many valley glaciers may therefore be more complex than is often assumed, and the configuration and behaviour of the glacial drainage network may also act as a control on ice-margin geomorphology and sedimentology as well as on subglacial processes.

This interpretation of active ice-marginal sedimentation raises three further questions: How does the debris get into the conduits? Why are the conduits located within the main body of the ice, rather than running at the bed as is commonly assumed/observed? And why is the debris returned from water to ice transport?

\section{Debris sources}

Ice flow which converges on a conduit will carry with it a steady flux of debris if the ice is dirty. Alternatively, a conduit which migrates through debris-rich ice can be expected to entrain large quantities of sediment. As with many alpine-type glaciers, Mueller and Tasman Glaciers receive a large supraglacial input of debris above the EL, much of which travels along high-level englacial pathways, and returns to the surface within the ablation area by upward ice flow. This leads us to anticipate a process whereby conduits running at high level through such debris-rich ice "hijack" its debris load.

However, with small outlet glaciers such as Gigjökull and Steinholtsjökull, such a mechanism cannot apply. With the exception of the sporadic airfall input of tephra (Hekla 1947 being the most recent example), supraglacial debris sources above the EL are negligible. Debris at high level below the EL must be derived from subglacial sources, before being carried from the basal transport zone into an englacial position. We infer that conduits collect debris, presumably from basal ice, whilst running at the bed, and subsequently leave the bed to take up an englacial route, so carrying the debris into high-level transport.

\section{Presence of a high-level conduit}

High-level conduits frequently have their origin at the surface, as when surface drainage is controlled by crevasses, for example (e.g. Stenborg, 1969). As discussed above, such conduits are likely to collect a substantial sediment load if they run through debris-rich ice. However, such simple behaviour cannot explain our observations at the two Icelandic study sites, because of the small quantity of englacial debris available to be tapped. Here, water within conduits which originate at the surface will be sediment-poor. Sediment-rich water at high level must have returned from the glacier bed, a feature which requires an alternative explanation. Of course, it is possible that this process also applies to Mueller and Tasman Glaciers, as well as many others world-wide.

Basic physics suggests that, given sufficient time, water will find its way to the bed of a glacier, and stay there, reasoning supported by the majority of field studies. Stable conditions under which water at the bed of a glacier subsequently takes an englacial route as we require here) apparently relate to situations in which drainage has to traverse an overdeepening, as is inferred for Glacier d'Argentière Hantz and Lliboutry, 1983), Storglaciären Hooke and others, 1988; Hooke and Pohjola, 1994) and South Cascade Glacier Hodge, 1976; personal communication from A. G. Fountain and J. S. Walder, 1993). We suggest that this also applies to Gigjökull and Steinholtsjökull and possibly Mueller and Tasman Glaciers too. All four are believed to have an overdeepening below their terminal lobes.

Beneath an overdeepening the water pressure within conduits will tend to rise towards ice-overburden pressure, with the effect that conduit flow becomes unstable as it loses its low-pressure advantage relative to adjacent areas of distributed drainage. Lliboutry (1983) draws on the idea of a gradient conduit a hypothetical channel which sits within the ice at its hydraulic grade line Röthlisberger, 1972) to argue that the most favoured route across an overdeepening is by means of a marginal gradient conduit at the level of the lip down-glacier. With this scenario, the conduit "takes off' to find an englacial route at the head of the overdeepening. Alternatively, Hooke and others (1988), elaborated by Hooke and Pohjola (1994), draw on tracer studies at Storglaciären to suggest a scheme whereby water leaves the bed as it attempts to exit the overdeepening across an adverse slope. The tendency for water pressure to rise is further enhanced by conduit shrinkage through water freezing-on to conduit walls (Röthlisberger and Lang, 1987, p. 244-5) and/or clogging through frazil-ice growth (Strasser and others, 1996) because of the need to liberate heat to keep the water at its pressure-melting point. Whereas Röthlisberger and Lang (1987) and (personal communication, Fountain and Walder (1993)), envisage water forced out of collapsing conduits into some kind of basal distributed drainage system, Hooke and Pohjola (1994) argue that water takes up an englacial route, aided by a pressure gradient set up by differences in sub- and englacial conduit geometries. However, the new englacial conduits are much smaller, but more numerous, than their parent subglacial conduit, and have reduced flow velocities. 


\section{Return of debris to the ice}

Sediment abandoned within the glacier by water is likely to be incorporated rapidly into ice. Several plausible mechanisms exist. In the Hooke and Pohjola (1994) hypothesis the process is inbuilt: as the parent conduit divides, the sediment-transport capability of the new branches falls markedly. However, it is questionable whether these new flows would have sufficient force to carry clasts of $\approx 0.1 \mathrm{~m}$ diameter into an englacial position $>10 \mathrm{~m}$ above the top of the basal ice $(>20 \mathrm{~m}$ above the bed), as is observed at Gigjökull. Transient extreme highpressure events generated by conduit blockage might achieve sufficiently high flows; if not, it may be necessary to envisage a larger, debris-laden conduit previously established at high level: e.g. a conduit which originates at the surface (New Zealand examples?) or perhaps a "Lliboutry-type" conduit which "takes off" at the head of an overdeepening. Within an englacial channel, sedimentation processes analogous to those of meandering or braided subaerial streams (e.g. deposition after channel avulsion) could account for debris abandonment. Alternatively, debris might be returned to ice as discharge falls and the drainage network closes down at the end of the melt season.

\section{CONGLUSION}

We interpret large volumes of rounded debris within ice-marginal moraines at the study glaciers to be relict englacial-conduit fills. This implies that debris entrained by ice is subsequently entrained by water, and carried some distance before it is returned to the ice prior to deposition. We have explored the mechanisms by which this sequence of events might be accomplished. Pronounced moraines with rounded debris can be expected if (a) a large quantity of debris is carried within the englacial drainage network; (b) there is a tendency (however controlled) for this debris to be abandoned within the ice; and (c) ice-flow trajectories and ablation ensure that this debris congregates at the ice surface. The examples of Gigjökull and Steinholtsjökull suggest that, in certain cases, the presence of an overdeepening exerts some kind of structural control on this type of moraine formation by forcing debris-laden streams to leave the bed and take up an englacial route.

This study shows how the nature of the drainage network may affect both sediment transport through a glacier and the patterns of ice-marginal sedimentation which result. We suggest that the distinction between "glacial" and "fluvioglacial" transport pathways and their resulting landforms is often blurred, and that the complexity of the transition between the two should not be underestimated. Potentially, this may lead to incorrect interpretations of past ice-marginal facies: e.g. material believed to be reworked outwash which was, in fact, dumped directly out of ice.

\section{ACKNOWLEDGEMENTS}

A. Davies, A. Mackintosh, M. Skidmore and D. Sugden provided field assistance in Iceland. Funding from a variety of sources, including the Royal Society, the Carnegie Trust, and the Lamb-Meiklejohn Fund (University of Edinburgh), is gratefully acknowledged. The comments of D.N. Collins and two anonymous reviewers led to significant improvements in the manuscript.

\section{REFERENGES}

Ballantyne, C. K. 1982. Aggregate clast form characteristics of deposits near the margins of four glaciers in the Jotunheimen Massif, Norway. Nor. Geogr. Tidsskr., 36 2), $103-113$.

Boulton, G.S. 1978. Boulder shapes and grain-size distributions as indicators of transport paths through a glacier and till genesis. Sedimentology, 25 6), 773-799.

Broadbent, M. 1973. A preliminary report on seismic and gravity surveys on the Tasman Glacier, 1971-72. Wellington, New Zealand, Department of Scientific Industrial Research. Geophysics Division. (Report K/6/2/1.)

Evenson, E. B. and J. M. Clinch. 1987. Debris transport mechanisms at active alpine glacier margins: Alaska case studies. In Kujansuu, R and M. Saarnisto, eds. INQUA Till Symposium, Finland 1985. Espoo, Geological Society of Finland, 111-136. (Special Paper 3.)

Hantz, D. and L. Lliboutry. 1983. Waterways, ice permeability at depth, and water pressures at Glacier d'Argentière, French Alps. $\vec{f}$. Glaciol.. 29 (102), 227-239.

Hochstein, M. P., D. Claridge, S. Henrys, A. Pyne, D. Nobes and S. F. Leary. 1995. Downwasting of the Tasman Glacier South Island. N.Z.) : changes in the terminus region between 1971 and 1993. N.Z. J. Geol. Geophys., 38 (1), 1-16.

Hodge, S. M. 1976. Direct measurement of basal water pressures: a pilot study. J. Gilaciol., 16 (74), 205-218.

Hooke, R. LeB. and V.A. Pohjola. 1994. Hydrology of a segment of a glacier situated in an overdeepening, Storglaciären. Sweden. J. Glaciol., 40 (134), 140-148.

Hooke, R. LeB., B. Wold and J. O. Hagen. 1985. Subglacial hydrology and sediment transport at Bondhusbreen, southwest Norway. Geol. Soc. Am. Bull., 96 3), 388-397.

Hooke, R. LeB., S. B. Miller and J. Kohler. 1988. Character of the englacial and subglacial drainage system in the upper part of the ablation area of Storglaciären, Sweden. J. Glaciol., 34 117), 228-231.

Kirkbride, M.P. 1993. The temporal significance of transitions from melting to calving termini at glaciers in the central Southern Alps of New Zealand. Holocene, 3 (3), 232-240.

Kirkbride, M. P. 1995. Processes of transportation. In Menzies, J., ed. Modern glacial emvironments: processes, dynamics and sediments. Vol. 1. Oxford, Butterworth-Heinemann, 261-292.

Lliboutry, L. 1983. Modifications to the theory of intraglacial waterways for the case of subglacial ones. J. Glaciol., 29 102), 216-226.

Matthews, J.A. 1987. Regional variation in the composition of Neoglacial end moraines, Jotunheimen, Norway: an altitudinal gradient in clast roundness and its possible palacoclimatic significance. Boreas, 16 2), 173-188.

Powers, M. C. 1953. A new roundness scale for sedimentary particles. $\mathcal{J}$. Sediment. Petrol., 23 2), 117-119.

Röthlisberger, H. 1972. Water pressure in intra- and subglacial channels. f. Glaciol., 11 62), 177-203.

Röthlisberger, H. and H. Lang. 1987. Glacial hydrology. In Gurnell. A. M. and M.J. Clark, eds. Glacio-fluvial sediment transfer: an Alpine perspective. Chichester, etc., John Wiley and Sons, 207-284.

Slatt, R. M. 1971. Texture of ice-cored deposits from ten Alaskan valley glaciers. J. Sediment. Petrol., 41 3), 828-834.

Stenborg, T. 1969. Studies of the internal drainage of glaciers. Geogr. Ann., Ser. A, 51A $(1-2), 13-41$.

Strasser, J. C., D. E. Lawson, G.J. Larson, E. B. Evenson and R. B. Alley. 1996. Preliminary results of tritium analyses in basal ice. Matanuska Glacier, Alaska, U.S.A.: evidence for subglacial ice accretion. Ann. Glaciol., 22 (see paper in this volume). 